\title{
A sacramentalidade da Palavra de Deus Uma aproximação entre a mistagogia de Ambrósio de Milão e a Constituição Sacrosanctum Concilium
}

Orientador: Luiz Fernando Ribeiro Santana

Doutorando: André Luiz Benedito

Área de Concentração: Teologia Sistemático-Pastoral

Linha de Pesquisa: Fé e Cultura

Projeto de Pesquisa: Questões atuais de Teologia Litúrgica

A revalorização da Sagrada Escritura na celebração litúrgica foi uma das grandes conquistas no tocante à reforma dos ritos promovida pelo Concílio Vaticano II. A partir desse evento, tanto o Magistério como a reflexão teológica amadureceram essa temática, inclusive rumando para uma perspectiva da Palavra de Deus sob a ótica da sua sacramentalidade nas ações litúrgicas. A presente tese, então, inicia-se com esta abordagem suscitada pelas intuições da Constituição Sacrosanctum Concilium. Em vista de aprofundar o tema da sacramentalidade da Palavra, o estudo em questão recorre à teologia patrística, mais precisamente, a de Ambrósio de Milão, com enfoque nas suas duas renomadas obras mistagógicas: De Sacramentis e De Mysteriis. Nelas, há o recurso à tipologia bíblica, cuja finalidade é conduzir os neófitos à experiência do mysterium. O método tipológico de Ambrósio procura demonstrar aos recém-batizados que a "palavra eficaz" de Deus, manifestada na história salvífica, continua realizando sua missão de resgatar a humanidade. À luz das instruções pós-batismais de Ambrósio, a pesquisa buscou encontrar elementos teológico-pastorais em relação à sacramentalidade da Palavra de Deus nas celebrações litúrgicas. A pregação mistagógica de Ambrósio, com efeito, se revela profundamente atual e se apresenta hoje como fonte de inspiração para que as nossas comunidades - ainda em processo de recepção das propostas do Concílio - façam a experiência litúrgico-assembleal das Escrituras. A contribuição ambrosiana, nesse sentido, tem a 
potência de fazer com que os cristãos descubram a eficácia salvífica da Palavra proclamada nas celebrações da Igreja e se tornem capazes de responder a essa mesma Palavra no culto e na vida.

Palavras-chave: Palavra de Deus. Sacramentalidade. Escritura. Sacrosanctum Concilium. Ambrósio de Milão. Tipologia bíblica. Mistério. Salvação. Mistagogia. 